
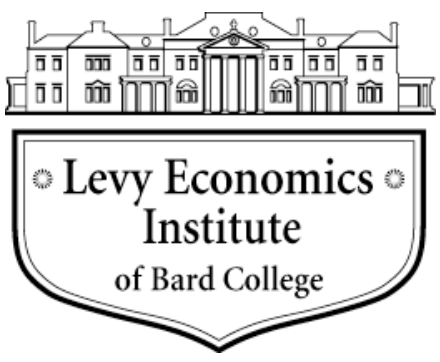

Working Paper No. 735

\title{
The Impact of Financial Reform on Federal Reserve Autonomy
}

by

\author{
Bernard Shull* \\ Professor Emeritus, Hunter College, CUNY \\ Special Consultant, National Economic Research Associates
}

November 2012

* This paper, the basis for remarks made at the Levy Economics Institute Plenary Session on Improving Governance of the Government Safety Net in Times of Crisis at the International Post Keynesian Conference in Kansas City, September 28, 2012, grew out of a presentation at the Levy Institute's 21st Annual Hyman P. Minsky Conference at the Ford Foundation in New York City on April 12, 2012.

The Levy Economics Institute Working Paper Collection presents research in progress by Levy Institute scholars and conference participants. The purpose of the series is to disseminate ideas to and elicit comments from academics and professionals.

Levy Economics Institute of Bard College, founded in 1986, is a nonprofit, nonpartisan, independently funded research organization devoted to public service. Through scholarship and economic research it generates viable, effective public policy responses to important economic problems that profoundly affect the quality of life in the United States and abroad.

Levy Economics Institute

$$
\text { P.O. Box } 5000
$$

Annandale-on-Hudson, NY 12504-5000

http://www.levyinstitute.org

Copyright (C) Levy Economics Institute 2012 All rights reserved

ISSN 1547-366X 


\section{ABSTRACT}

The Federal Reserve has been criticized for not preventing the risky behavior of large financial companies prior to the financial crisis of 2008-09, for approving mergers that aggravated the "too big to fail" problem, and for its substantial contribution to bailouts when their risk management failed. The Dodd-Frank Act of 2010, in attempting to diminish financial instability and eliminate too-big-to-fail policies, has established a new regulatory framework and laid out new responsibilities for the Federal Reserve. In doing so, it appears to address criticisms of the central bank by constricting its autonomy. The law, however, has also extended the Federal Reserve's supervisory authority and expanded its capacity to exercise regulatory control over its extended domain. This new authority is in addition to the augmentation of its monetary powers over the past several years.

This paper reviews and evaluates both constraints imposed on the Federal Reserve by the Dodd-Frank Act and the expansion of Federal Reserve authority. It finds that the constraints are unlikely to have much impact, but the expansion of authority constitutes a significant increase in power and influence. The paper concludes that the expansion of Federal Reserve authority invites questions about the organizational design and governance of the central bank, and its traditional autonomy.

Keywords: Financial Crisis; Federal Reserve; Government Policy and Regulation JEL Classifications: G01, G28 


\section{INTRODUCTION}

The Federal Reserve took on an expanded role as lender-of-last-resort in attempting to moderate the financial crisis of 2008-09 and the recession that followed. ${ }^{1}$ It has, nevertheless, been criticized for not preventing the risky behavior of large financial companies prior to the crisis, for approving their mergers that aggravated the "too-big-to-fail" problem, and for its substantial contribution to bail-outs when their risk management failed. As might be expected, the DoddFrank Act of 2010 contains provisions that appear to limit the Federal Reserve System's (Fed's) autonomy. ${ }^{2}$ Among other things, it has folded the Fed into a new, overarching regulatory agency, restricted its functioning as a lender-of-last resort, subsumed its judgments to that of the Treasury in important credit extension matters, augmented Government Accountability Office (GAO) review to fortify congressional oversight, modified Reserve Bank governance to enhance the dominance of the presidentially-appointed Board of Governors, and added a "systemic risk" factor to the Board's prior assessment of large bank mergers.

At the same time, Dodd-Frank has also extended the Fed's supervisory authority and expanded its capacity to exercise control over the behavior of those it regulates. This growth in authority is in addition to other changes in monetary powers over the past several years that have augmented its power and influence.

This paper reviews and evaluates constraints imposed on Federal Reserve autonomy by Dodd-Frank, and also the expansion of its authority, both by the law and in other ways. It finds that the constraints are not likely to be significant, but that the augmentation of authority is. It is more the augmentation than the constraints that invites questions about the Fed's autonomy.

\section{THE ORIGIN AND NATURE OF FEDERAL RESERVE AUTONOMY}

Central banking practices in Europe in the latter part of the $19^{\text {th }}$ and early $20^{\text {th }}$ centuries were aimed at protecting gold reserves through interest rate adjustments and, when necessary, providing emergency assistance in financial crises. In general, central banks operated without

\footnotetext{
${ }^{1}$ See Bernanke, 2012. Hyman Minsky, observing changes in financial markets and instruments over forty years ago, anticipated the need for the expansion of lender-of-last resort responsibilities. See, for example, Minksy, 1969, pp. 189-90.

${ }^{2}$ Relevant provisions of the Dodd-Frank Act are often separately applicable to the Board of Governors and the Reserve Banks. Nevertheless, except where necessary the term "Federal Reserve" or "Fed" is used without specific reference to the former or latter.
} 
direct concern for resource allocation, income distribution or the well-being of individual businesses. "To say openly that the Bank [of England] was trying to control the banking system," Joseph Schumpeter remarked, "let alone to manage the general business situation, would have evoked laughter if not indignation: the thing to say was that the Bank...harbored no pretensions at controlling anything or anybody."3

Even this degree of unobtrusiveness constituted an excessive concentration of private power to the founders of the Federal Reserve System. They did not envision a European-style "central bank." They saw the Fed as a decentralized, joint banking venture, reined-in by checks and balances within, and overseen, but not managed, by the government. Within the confines of the gold standard, individual Reserve Banks would independently provide the currency demanded by the public, and particularly in times of financial crisis. Congress gave the Fed authority to clear and settle payments. And it provided supervisory authority over member banks. But with the Comptroller of the Currency remaining as the principal supervisor of national banks, this authority soon shrunk to include only those that were state-chartered.

The Fed's independence derived from its organizational architecture whose purpose was to allow banks, for the most part, to handle their own problems. ${ }^{4}$ The System's monies were not tied to the congressional budget, its Board members had long terms of office, and its geographically-diverse Reserve Banks were supervised by boards of directors, representing business, banking and the public, chosen by its member banks and the Board.

The architecture left the Fed with three principal constituencies: Congress that maintained oversight, the President who chose its Board members, and the bankers who owned the Reserve Banks. ${ }^{5}$ When the Fed began to exercise monetary powers for purposes of stabilization about a decade after its establishment, its principal leader, Benjamin Strong, recognized the need for independence from political pressure. ${ }^{6}$ This theme has been emphasized

\footnotetext{
${ }^{3}$ Schumpeter, 1954, p. 696.

${ }^{4}$ Carter Glass' House Committee that wrote the principal bill that became the Federal Reserve Act viewed the Fed as relieving the government of its involvement with banks, in line with the aims of the Independent Treasury System established during the presidency of Martin VanBuren. See U.S. House of Representatives, 1913, pp. 29-30.

${ }^{5}$ For an analysis of the relative importance of these constituencies in the period between 1959 and 1993, see Shull, 1995-96, pp. 227 ff. (Appendix).

${ }^{6}$ See Strong, 1922. Strong observed: "The natural inclination of the Administration...to ...make business good....Invariably that key is...the Federal Reserve System....cheap money, abundant credit....rising prices....".
} 
by Fed officials over the years. ${ }^{7}$ It has been supported over the last several decades by crosscountry research that found central bank independence to be a significant factor in preventing inflation. ${ }^{8}$

The organizational basis for independence and the relative importance of the System's constituencies have, over time, been modified. The Banking Act of 1935 established the Board as dominant, in part by providing it with a majority on the Federal Open Market Committee, and it loosened its direct ties to the Executive branch by eliminating the Secretary of the Treasury and Comptroller of the Currency as ex-officio members. The Humphrey-Hawkins bill of 1978 provided for additional congressional oversight. But the basic design has remained unchanged.

In the regulatory area, in contrast to its monetary independence, the Federal Reserve's autonomy stems from the quasi-legislative and judicial authority normally provided regulatory agencies. The Fed's regulatory policies and practices, unlike its traditional monetary policy, are firm-specific, directly affecting individual companies.

When established, as noted, the Fed's regulatory role was modest. However, the Banking Act of 1933 and subsequent legislation gave it sole authority over bank holding companies. The emergence of the bank holding company as the organizational structure of choice for all major banking companies established the Federal Reserve as the dominant bank regulator.

The Fed's regulatory authority and, in particular, its prior approval authority over proposed mergers and acquisitions by holding companies, has, in recent decades, been determinative. Over the last quarter-of-a-century, it has had little interference from courts or congress. Fed approvals have resulted in a radical increase in concentration, creating and enlarging banking companies "too-big-to-fail." Neither concerns about the impact on competition of this development, nor concerns as to "safety and soundness" found their way into the Board's decisions approving large bank combinations. ${ }^{10}$

There have, periodically, been serious challenges to the Fed's regulatory authority, with proposals that it be transferred to other agencies. The Fed has vigorously and successfully

\footnotetext{
${ }^{7}$ See Volker, 1986, p. 186 and McDonough, 1994, p. 5.

${ }^{8}$ For additional discussion of Federal Reserve independence, and a review of these issues, see Shull, $1995-96$.

${ }^{9}$ Between 1980 and 2009, the deposits held by the five largest commercial banks in the U.S. increased from about 12 percent to 43 percent. For information on the growth of the largest banking companies through mergers and acquisitions, see Shull, 2010, Appendix A.

${ }^{10}$ In the late 1980 s, Treasury officials, as well as Alan Greenspan, supported the creation of so-called "superbanks" that could better compete with Japanese and European banking companies. See Nash, 1989.
} 
opposed such proposals, arguing that regulatory authority is critical to its monetary policy responsibilities. "[A]s the nation's central bank [it] must remain substantively involved in the regulation and supervision of the financial and banking system because those functions impinge upon its general responsibilities."11 And, “...it would be dangerous...to look to the Federal Reserve to 'pick-up-the-pieces' in a financial crisis without also providing [it]...with the tools...to reduce the likelihood of a crisis arising." 12

The exercise of substantial economic power by a relatively independent Federal Reserve, has, nevertheless, provoked objections by those who have found the economic rationale and/or political justification inadequate. Objections have encompassed both the Fed's monetary and regulatory authority, and have moved from academic journals to the public press. ${ }^{13}$

\section{DODD-FRANK PROVISIONS}

As noted, a number of Dodd-Frank Act provisions impose constraints on the Fed; others augment its authority. They are reviewed below.

\section{A. New Supervisory Framework}

The law establishes the Financial Stability Oversight Council (FSOC), chaired by the Secretary of the Treasury and reporting to Congress. The FSOC includes the heads of the federal agencies with financial sector responsibilities, including the Chairman of the Board of Governors. Its purpose is to identify and monitor systemic threats from the financial system, recommend responses and make legislative proposals to address issues that arise. A new Office of Financial Research (OFR), also reporting to Congress, has been established to assist the FSOC in meeting these objectives.

The Fed continues as the supervisor of bank holding companies, with strengthened authority over their bank and nonbank subsidiaries. ${ }^{14}$ It has also been given authority over savings and loan holding companies, transferred from the now defunct Office of Thrift

\footnotetext{
${ }^{11}$ See Board of Governors, 1984, p. 547.

${ }^{12}$ Ibid., pp. 548-49.

${ }^{13}$ For some recent pronouncement on the subject, see Taylor, 2012, p. A19 and Shultz, et al., 2012, p. A19

${ }^{14}$ See Tarullo, 2012, pp. 4-5. The Gramm-Leach-Bliley Act (1999) had placed restrictions on the Fed in examining subsidiaries of bank holding companies regulated by other agencies.
} 
Supervision. ${ }^{15}$ On the recognition that the financial crisis emanated, in part, from the risky activities of investment banks and insurance companies, the Fed is also charged with supervising nonbank financial institutions designated as systematically important (SIFIs) by the FSOC. All bank holding companies with over $\$ 50$ billion assets are also classified as systemically important. ${ }^{16}$

The Fed is required to impose "enhanced prudential standards" on the SIFIs it supervises, including higher capital, leverage and liquidity requirements, albeit subject to recommendations by the FSOC. In addition, all SIFIs must develop “orderly resolution" plans ('living wills'). ${ }^{17}$ These are intended to permit their liquidation without systemic impact. ${ }^{18} \mathrm{~A}$ former chairperson of the FDIC, Sheila Blair, has stated that the Fed and the FDIC may need to require organizational changes that "rationalize" large banking company structures because “...there is a real danger that their complexity could make a SIFI resolution far more costly and more difficult than it needs to be." 19

If the Fed and the FDIC jointly determine that a company's resolution plan is not credible, the Fed is authorized to impose still more stringent balance sheet requirements and also to restrict growth and/or specific activities. If a company does not submit a credible resolution plan within two years after these measures have been imposed, the Fed may determine that it 'poses a grave threat to financial stability.' On a two-thirds vote of the FSOC, it can restrict on

\footnotetext{
${ }^{15}$ Dodd-Frank transfers the supervision of federally-chartered thrift institutions from the Office of Thrift Supervision to the Office of the Comptroller of the Currency, and transfers state-chartered thrifts to the FDIC. ${ }^{16}$ The Dodd-Frank Act indicates some of the factors to be applied by the FSOC in making such designations. These include a company's "scope, size, scale, concentration, interconnectedness and other factors that could pose a threat to the financial stability of the United States." It, thus, leaves room for other factors that the FSOC finds relevant. As of this writing, the FSOC has yet to designate any nonbank financial institution as systematically important. In July, 2012, it did designate eight "financial market utilities" (clearing or settlement systems) as systematically important.

${ }^{17}$ The Fed and FDIC have jointly issued rules for the development of 'living wills.' The initial plans for the largest holding companies were published, in part, in July 2011. These companies are required to report periodically to the Fed, the FDIC and the FSOC on their resolution plans. In addition, they are to report on their credit exposure to other significant financial companies and the extent to which other significant financial companies have credit exposures to them.

${ }^{18}$ See Blair, 2011.The FDIC can also take a failed banking company into receivership so that it continues to function (e.g., as a "bridge bank") until sold.

${ }^{19}$ See Blair, 2011. Blair has also argued that "[u]nder the new...resolution framework, the FDIC should have a continuous presence at all designated SIFIs...as part of their normal course of business."
} 
mergers, acquisitions, specific financial products offered by the offending company, and require it to terminate activities and to sell assets; i.e., to divest. ${ }^{20}$

\section{B. Emergency Lending, GAO Audits, and Reserve Bank Directors}

The new law imposes additional constraints on the extension of credit in emergencies to nonbanks, audits by the Government Accountability Office (GAO) and the selection of Reserve Bank presidents by their boards of directors. ${ }^{21}$

\section{Credit Extension in Exigent Circumstances}

The Fed's authority to extend emergency credit to nonbanks [Section 13(3)] has been modified to prohibit it from targeting specific nonbank companies for rescue, as it did in the course of the financial crisis with AIG. Dodd-Frank permits it to provide credit to "individuals, partnerships and corporations" (IPCs), in "unusual and exigent circumstances" within a "facility or program with broad-based eligibility." The Fed must have Treasury approval to establish such programs, must consult with the Treasury as to policies and procedures, and must provide reports to Congress.

\section{GAO Audit and Other Information}

The Federal Banking Agency Audit Act (1978) gave the GAO authority to audit the Fed and for the public release of information. ${ }^{22}$ However, it barred the GAO from monetary policy areas, including transactions with foreign central banks and governments, deliberations with regard to monetary policy, FOMC directives and related internal communications.

Dodd-Frank provides for several types of GAO audits, including a one-time review of all loans and other Fed transactions related to its emergency financial assistance during the financial crisis between December 1, 2007 and July 21, 2010. This has now been accomplished.

\footnotetext{
${ }^{20}$ Sec. 121(a); and Sec. 165(d). Also see Tarullo, 2012, p. 7.

${ }^{21}$ These are found in Title XI, "Federal Reserve Provisions." Section 1101 deals with emergency credit; Sections 1102, 1103 and 1109 deal with the audit authority of the Government Accountability Office (GAO). Sections 1107, 1108 relate to Federal Reserve governance. The other sections of the Title (Sections 1104, 1105, and 1106) repeal earlier FDIC emergency credit authority and provide for the determination of a "liquidity event" that would permit the FDIC to provide assistance to insured depository institutions in periods of financial stress. Such liquidity events are to be determined in consultation with the Treasury.

${ }^{22}$ For a review of both audit and disclosure requirements, see Alvarez and Baxter Jr., 2011,
} 
The restriction on the audit of monetary policy deliberations and determinations were, however, left in place. $^{23}$

\section{Reserve Bank Directors}

Since passage of the Federal Reserve Act in 1913, Reserve Bank presidents have been selected by the nine directors at each of the twelve Banks. These include three directors in each of three classes: A (bankers elected by member banks), B (non-bankers elected by member banks) and C (non-bankers appointed by the Board to represent the public). Under the Dodd-Frank Act, Reserve Bank presidents are to be selected only by Class B and C directors alone.

\section{New Merger Restrictions}

In approving mergers and acquisitions, the Fed must now consider the risk posed by any combination to the stability of the U.S. banking or financial system. ${ }^{24}$ The law also prohibits mergers and acquisitions of financial companies that would bring the resulting firm's consolidated liabilities to more than 10 percent of the aggregate consolidated liabilities of all financial companies nationwide. ${ }^{25}$ A previous 10 percent limit had applied only to banking companies and deposits of insured depository institutions. It had invited circumvention through the acquisition of firms with non-deposit liabilities. ${ }^{26}$

\section{EXPANDED AUTHORITY AND CONSTRAINTS}

\footnotetext{
${ }^{23}$ The audit covered the Fed's operational integrity and internal controls, security and collateral policies, fairness to all institutions and the use of contractors to manage credit programs.

${ }^{24}$ It should be noted that separate legislative provisions, with somewhat different standards, govern the Fed's review of several different types of proposed bank mergers and acquisitions. But all now require that the Fed consider risk to financial stability. See Tarullo, 2012, pp. 8, 15 ff, 28, notes 21 and 31. Also see Dodd-Frank, Title VI, Section 604 (d), (e), (f). Dodd-Frank also provides that financial holding companies that have $\$ 50$ billion or more in assets must now notify the Board before acquiring ownership or control of companies with $\$ 10$ billion or more in assets that are engaged in "permissible" nonbanking activities [Sec 163 (b)(4)] and consider whether these acquisitions would result in additional risk to financial stability.

${ }^{25}$ Sec. 622. Liabilities are defined as "risk-weighted assets minus regulatory capital."

${ }^{26}$ The previous limit was established by the Riegle-Neal Interstate Banking and Branching Efficiency Act of 1994, Title I, Sec. 101. It derived from congressional concern about the competitive dominance of large banks as a consequence of the Act's relaxation of interstate branching restrictions (See Shull and Hanweck, 2001, pp. 15570).
} 
The provisions reviewed above suggest a congressional intent to expand Fed authority, but to constrain it by requiring Treasury or FSOC approval, by more rigorous congressional oversight and by diminishing the influence of the banking community. As is the case with all new legislation, it is no simple matter to determine outcomes from legal language alone. Putting words into a statute book, the legal scholar Willard Hurst observed, is only part of the process. "The text derives its vitality...from its past...[and] from what those charged with applying it do to give it force....." ${ }^{, 27}$ With this understanding, we consider the provisions reviewed above to form expectations as to their overall consequences.

First, we consider the FSOC. Fortified by the OFR, it seemingly provides the Treasury and/or Congress, through oversight, with the facility to exert a controlling influence on critical regulatory decisions by the Fed. However, the actual nature of the complex relationship that the law now requires between the Fed and the FSOC is unlikely to be clear for some time. An important consideration is that the Federal Reserve remains the principal supervisor for all major bank and nonbank financial companies. Its unique day-to-day, hands-on information, coupled with its own formidable resources and research facilities, is conducive to it being the most important, if not the dominating, agency involved in the process of assessing risk and implementing remedies.

The new restriction on Fed lending to nonbanks in exigent circumstances directly raises the Hurst caveat on the difference between the legal language and actual conduct. The FDIC Improvement Act (FDICIA, 1991) included a "systemic risk exception" that permitted regulatory agency assistance to failing companies that posed a systemic threat. But invoking the exception required a joint determination by the Fed and the Treasury (with agreement by the President). The joint determination proviso was not invoked when, in 1998, the Fed determined that the failure of Long-Term Capital Management (LTCM) would disrupt financial markets. Rather, it organized a private lending consortium to prevent the collapse. ${ }^{28}$

The effectiveness of the constraint on extensions of credit by the Fed to nonbanks in exigent circumstances is similarly tenuous. It is plausible that the Fed could find ways around

\footnotetext{
${ }^{27}$ Hurst, 1982, pp. 40, 41.

${ }^{28}$ On the Fed's involvement with LTCM, see Lowenstein, 2000, pp. $194 \mathrm{ff}$. On the role of consortiums in notable crises of the past, see Shull, 2005, pp. 29-35 and pp. 38-39.
} 
the limitation as it did in the case of LTCM. But such circumvention might not normally be necessary. The Fed's recommendations are likely to be sufficient for the Treasury and the FSOC to conclude that the failure of one or more nonbanking companies poses a systemic threat and requires intervention. ${ }^{29}$

For some time, the Fed has maintained that GAO audits of monetary policy deliberations and determinations would expose its policy decisions to political pressure. There are a number in Congress who, nevertheless, believes that extended GAO audits are necessary. ${ }^{30}$

GAO audits of the Federal Reserve have a long history. When first established, the Fed was audited by the Treasury Department. In 1921, auditing was transferred to the newly created GAO. The Banking Act of June 16, 1933, declared that Federal Reserve monies were neither public nor appropriated funds and, therefore, it was not subject to GAO audit. From then until 1978, the Board examined the Reserve Banks, and outside auditors examined the Board. The Federal Banking Agency Audit Act of 1978 again authorized GAO audits for all Federal Reserve operations, but excepted monetary policy-related matters.

This varied experience might possibly provide evidence on the impact of GAO audits on the Fed's monetary policy independence. To date, the issue is beset by conflicting opinions and unsupported speculation.

The new voting arrangement for Reserve Bank presidents appears to shift power from member banks to the Board (which will now select half of the voting directors rather than onethird). However, since the Banking Act of 1935, the appointment of Reserve Bank presidents and first vice presidents has been subject to approval by the Board of Governors. ${ }^{31}$

There are anecdotal suggestions that the Board has exercised its authority, but no publicly available information on the extent to which this has been the case or for what reasons.

\footnotetext{
${ }^{29}$ The government has, in crises and difficult economic times, been assertive in having the Fed make such loans. Congress initially provided authority to the Fed for loans to nonbanks in the Emergency Relief and Construction Act of July 1932, and further elaborated the authority in the Emergency Banking Act of March, 1933 and the Industrial Advances Act of June, 1934. It did not revoke the authority until 1958, and then on the view that it was no longer necessary. It restored the authority in the wake of the S\&L debacle and commercial bank real estate problems on passing FDICIA in 1991.

${ }^{30}$ Current restrictions on GAO audit in the monetary policy area and the rationale for extending audits are elaborated in the Federal Reserve Transparency Act of 2012

${ }^{31}$ Sec. 4, Banking Act of 1935.
} 
In any event, the Board's authority to reject selections is likely to be effective in shaping Reserve Bank elections. The new voting restriction appears redundant.

The addition of a "systematic risk" factor to the Fed's appraisals of mergers and acquisitions is, at best, a modest constraint. As Board member Daniel K. Tarullo explained, it leaves the Governors with extensive discretion. Congress, he said,

“...did not instruct us to reject a proposed acquisition simply because there would be any increase in [systemic risk] ....[W]e have been instructed to add any increased systemic risk to the list of adverse effects that could result from the merger and then determine whether the benefit to the public of the acquisition outweigh these adverse effects." 32

Governor Tarullo pointed out that a combination resulting in a company that constituted a systemic risk could still be approved if the risk was offset by benefits; e.g., a lesser likelihood of failure, a capacity to fill the gap if a competitor failed, increased competition and greater efficiency.

This formulation was implemented in two recent decisions-the acquisition of the Royal Canadian Bank offices by PNC; and the acquisition of ING by Capital One. ${ }^{33}$ In the latter case, the $8^{\text {th }}$ largest depository organization in the United States $\left(\$ 127\right.$ billion) acquired the $17^{\text {th }}$ largest ( $\$ 82$ billion). Capital One, thereby, became the $5^{\text {th }}$ largest depository institution in the United States. ${ }^{34}$ The Fed found that any adverse systemic risk consideration was more than offset by the benefits of the combination.

The new 10 percent limit leaves no room for discretion. But neither did the previous limit. It remains to be seen whether the new one will be binding. Neither the addition of a new

\footnotetext{
${ }^{32}$ Tarullo, 2011, pp. 5, 6..

${ }^{33}$ The Federal Reserve Board approved the first mentioned acquisition in December 2011, and the second in February, 2012.

${ }^{34}$ The Fed considered the systemic risk factor and concluded that it was "consistent with approval." Capital One, Order Approving the Acquisition of a Savings Association and Nonbanking Subsidiaries, Federal Reserve Board Order No. 2012-1, February 14, 2012, pp. 28-40. Factors reviewed included the existence of substitute providers should Capital One fail, "interconnectedness" that might transmit distress to other institutions or markets, "complexity" that might "hinder timely and efficient resolution," and "cross-border activity" that might complicate coordinating resolution.
} 
systemic risk factor nor the 10 percent limit constraint would seem to affect the Fed's autonomy materially. $^{36}$

It is worth noting that even if the limit is binding, and even if the systemic risk factor is interpreted restrictively, there is still no assurance that increases in concentration among the largest banking companies will be diminished or even stemmed. Given their likely advantages, including those related to being "too-big-to-fail," there is nothing to prevent them from growing internally. $^{35}$

In summary, none of the specific constraints reviewed above can be seen, with a reasonable degree of likelihood, as limiting the Federal Reserve autonomy in a substantial way. On the other hand, there is no doubt about the extension of Fed authority to nonbanking financial companies, and the expansion of its supervisory powers well beyond traditional measures.

\footnotetext{
${ }^{36}$ An alternative approach would be to combine the aggregate limit with the systemic risk appraisal in merger review by imposing a progressively increasing negative weight for proposed combinations as they approached the limit.

${ }^{35}$ Widespread recognition that the new merger provisions are not likely to limit, much less reduce, concentration is implied in recent proposals from well-known financial sector authorities to break-up large, systemically-important banking companies or, at least, to cap their growth. These include some prominent System officials. Governor Tarullo has suggested a limit on financial company size related to Gross Domestic Product (Tarullo, 2012, p. 2324). The presidents of the Federal Reserve Bank of Dallas and Richmond have publicly called for the break-up of large financial companies.
} 


\section{AUTHORITY AND AUTONOMY}

Dodd-Frank aside, the Fed has also expanded its monetary influence over the course of the recent crisis. It obtained authority to pay and alter interest on reserves, a power it now views as a monetary tool. ${ }^{36}$ It has developed a program of "forward guidance" to generate public expectations as to the long-term future of short-term interest rates, another policy tool. It introduced a variety of non-traditional, credit-extension programs to support various segments of the financial system. And it has broadened its portfolio by purchasing long-term Treasuries and mortgage-backed securities. In the process, it has expanded its portfolio enormously. It stated aims have included the stimulation of the stock and real estate markets.

The growth of Fed power and influence has been accompanied by a new level of public awareness supported by both legislative requirements and the Fed's own commitment to "transparency." To the public, the Fed is no longer a little-known organization, manipulating obscure variables far removed from daily life; an organization oblivious to the relative wellbeing of distinct groups of businesses and individuals. It is now widely understood that its regulatory policies, by intention, impact the viability of companies beyond banking, and that its monetary measures have differential impacts on markets and business groups, savers and spenders, creditors and debtors; that is, on different segments of the public.

Its power, coupled with public awareness, portends an autonomy issue that transcends the Dodd Frank constraints. Who is to exercise control and under what circumstances? Is control to be subject to the kinds of checks and balances that the designers of the Federal Reserve originally established? Is control to be in the hands of a few public officials whose policies and practices are normally disconnected from elected representatives? Is it to be in the hands of the Treasury and/or Congress? Or is the issue of control to be dealt with in some other way?

\section{CONCLUSIONS}

The Dodd-Frank bill has attempted to prevent financial instability and eliminate too-big-to-fail policies by establishing a new regulatory framework and laying out new responsibilities for the

\footnotetext{
${ }^{36}$ The Financial Services Regulatory Relief Act of 2006 gave the Fed authority to take effect in 2011 . The date was moved up to October 1, 2008 by the Emergency Economic Stabilization Act, 2008.
} 
Federal Reserve and other financial regulatory agencies. In doing so, it seeming imposed constraints on traditional Fed autonomy.

An evaluation of these constraints suggests that they are unlikely to have much impact on the Fed. At the same time, other provisions of Dodd-Frank and other developments surrounding the financial crisis of 2008-09 have expanded the Fed's power and influence enormously.

Central banking autonomy has, for many years been subject to controversy. Recent developments suggest that the likely limits of the Dodd-Frank constraints, coupled with the recent expansion of the Federal Reserve's monetary powers, require a rethinking of its organizational design. 


\section{REFERENCES}

Alvarez, Scott G., and Thomas C. Baxter Jr., 2011, "Federal Reserve Lending Disclosures,"

Testimony Before the Subcommittee on Domestic Monetary Policy and Technology, Committee on Financial Services, U.S. House of Representatives, Washington, D.C. June 1.

Bernanke, Ben S., 2012, "Monetary Policy Since the Onset of the Crisis," Speech at Federal Reserve Bank of Kansas City Symposium, Jackson Hole, Wyoming, August 31.

Blair, Sheila, 2011, "We Must Resolve to End Too Big to Fail," "Remarks at a Conference on Bank Structure and Competition,” Federal Reserve Bank of Chicago, May 5.

Board of Governors of the Federal Reserve System, 1984, "The Federal Reserve Position on the Restructuring of Financial Responsibilities,” Federal Reserve Bulletin, July, pp. 547-557.

Federal Reserve Board, 1923, Annual Report, Washington, D.C.

Hurst, Willard, 1982, Dealing with Statutes, Columbia University Press, N.Y.

Lowenstein, Roger, 2000, When Genius Failed, Random House, New York

McDonough, William, 1994,“An Independent Central Bank in a Democratic Country: The Federal Reserve Experience," Federal Reserve Bank of New York Quarterly Review, Spring, pp. $1-6$.

Minsky, Hyman, 1982, Can 'It' Happen Again?, M. E. Sharpe, Inc., Armonk, N.Y.

Nash, Nathaniel C., 1989, “Treasury Now Favors Creation of Huge Banks,” New York Times, June 6, p.1. 
Schultz, George P. et al., 2012, “The Magnitude of the Mess We're In,” Wall Street Journal, Sept. 17, p. A19.

Schumpeter, Joseph A., 1954,, A History of Economic Analysis, Oxford University Press, New York

Shull, Bernard, "Too-Big-to-Fail in Financial Crisis: Motives, Countermeasures, and Prospects," Working Paper No. 601, Levy Economics Institute, June 10, 2010.

Shull, Bernard, 2005, The Fourth Branch: The Federal Reserve's Unlikely Rise to Power and Influence, Praeger, Westport, Conn.

Shull, Bernard, 1995-96, "Federal Reserve Independence: What Kind and How Much?," with an Appendix by Shull and Kevin Jaques, "Federal Reserve Reaction to Constituency Pressure," Journal of Post-Keynesian Economics, Winter, pp. 211-230.

Shull, Bernard and Gerald A. Hanweck. 2001. Bank Mergers in a Deregulated Environment. Westport, CT: Quorum Press.

Strong, Benjamin, 1922, "Memorandum to Carl Snyder," February 28, pp. 2,3, in "Strong Papers Archives," Federal Reserve Bank of New York

Tarullo, Daniel K., 2012, “Remarks on Financial Stability Regulation,” Distinguished Jurist Lecture, University of Pennsylvania Law School, Philadelphia, Pa., October 10.

Tarullo, Daniel K., 2011, “Industrial Organization and Systemic Risk,” Remarks at a Conference Regulating Systemic Risk, Washington D.C., Sept. 15, 2011.

Taylor, John B., 2012, “The Dangers of an Interventionist Fed,” Wall Street Journal, March 29, p. A19. 
U.S. House of Representatives, 2012, Federal Reserve Transparency Act of 2012, Report of Committee on Oversight and Government Reform with Minority Views, Report No. 112-607, 112th Cong., 2d Sess., July 172012

U.S. House of Representatives, 1913, Changes in the Banking and Currency System of the United States, Report of the Committee on Banking and Currency, $63^{\text {rd }}$ Congress, $1{ }^{\text {st }}$ Session, Washington D.C., September 9.

Volker, Paul, 1986, "Statement," Federal Reserve Bulletin, March, pp.184-90 at p. 186. 